\title{
Analysis of the Effect of ICT Education and Training, Professionalism and Performance of Elementary Teachers on the Quality of Learning in the KKG Group in Telawang, Banjarmasin
}

\author{
M. Mulyadi Rakhman *, Juhriyansyah Dalle, Suhaimi \\ BTIKP of Kalimantan Selatan Province, Universitas Lambung Mangkurat, Banjarmasin 70123, Indonesia
}

Article history:

Submission July 2020

Revised October 2020

Accepted October 2020

${ }^{*}$ Corresponding author:

E-mail:

mmulyadirakhman100@gmail.com

\begin{abstract}
The purpose of this research is to describe and determine ICT education and training, professionalism, and performance of elementary school teachers in KKG Group Telawang, Banjarmasin on the quality of learning. Also, to know the effect of professionalism on the performance of elementary school teachers in the KKG group Telawang, Banjarmasin. The quantitative method with the population and samples from elementary school teachers in KKG group Telawang, Banjarmasin. This research indicates that (1) the objective of improving teacher performance is to realize a good and quality learning process that requires education and training to improve professional competence, performance, and quality of learning, (2) There is an teacher professionalism influence on the performance of elementary school teachers in the KKG group in Telawang Banjarmasin with teacher professionalism, (3) There is an influence between ICT education and training on the quality of elementary teacher learning in the KKG group in Telawang Banjarmasin with the education and ICT training, (4) there is an influence between the teacher's professionalism on the quality of elementary school teacher learning in the KKG group in Telawang Banjarmasin and the professionalism of the teacher, (5) There is an influence between ICT education and training on the quality of buyers teachings of elementary school teachers in the KKG group in Telawang Banjarmasin with ICT education and training, (6) There is an influence of ICT education and training, teacher professionalism, and teacher performance on the quality of learning carried out by elementary school teachers who are members of KKG group Telawang Banjarmasin. All of them gave a positive and significant influence in ICT education and training on the performance and professionalism of elementary school teachers in the KKG Group in Telawang, Banjarmasin, which impacted the quality of learning the KKG.
\end{abstract}

Keywords: ICT education and training, professionalism, teacher performance, quality learning

\section{Introduction \\ Background}

An organization's success is mostly determined by the quality of the people who work in it (Nixon et al., 2012). Human Resource Management's role in an organization is not only administrative but rather more directed at how to be able to develop the potential of
Human Resources to be creative and innovative (Taunay, 2015) Human Resources actions influence an organization's outcome by providing examples of how it should play a role in the organization that can improve work performance if it continues to be consistent (Jiang et al., 2012). Included in Human Resources are educators in Indonesia who are required to display

\section{How to cite:}

Rakhman, M. M. (2020). Analysis of the effect of ICT education and training, professionalism and performance of elementary teachers on the quality of learning in the KKG group in Telawang, Banjarmasin. Journal of K6, Education, and Management, 3 (3), 279 - 294. doi: 10.11594/jk6em.03.03.02 
a variety of learning models following the learning process in the globalization era that affects the curriculum; thus, the educators' quality needs to be improved. This situation can be started by increasing the competence of educators, both in the delivery of learning materials, using appropriate teaching models and strategies, and using instructional (Trianto, 2010), including one of them using computer multimedia in learning (Ghavifekr \& Rosdy, 2015).

What is the teacher? The teacher is an excellent guide to where young people (students) should lead (Cassidy, 1921). Teachers also are intellectuals and teach morals (Santoro, 2011). According to Saryono (2012), a professional educator should be able to appropriately deliver learning materials according to students' needs. The rapid development of information and communication technology requires students to master the use of computers (Afshari et al., 2009) to direct students correctly in this modern era. So that teachers can apply ICT to support the learning process, breakthrough efforts are needed so that teachers have competence in the ICT field (Andoh, 2012). For example, ICT training for formal and non-formal teachers has been carried out by the Office of Education through the BTIKP South Kalimantan Province. It shows that providing adequate training and improving performance can also improve learning. It also shows that the organization that houses education is essential in allocating Human Resources (De Witte et al., 2019). Besides, teachers' collaboration can also be an essential key in developing an education system that helps student performance through the teacher's professional learning (Tóth-Pjeczka, Rapos, \& Szivák, 2019).

There are various reasons to encourage someone to be a teacher, perhaps because of work with stable hours, having a permanent holiday, and not much change (Nano, Kallciu, \& Mita, 2019). However, according to Munir (2014), teachers also need to adopt new roles as technology users. Teachers' capacity to use ICT effectively to improve the quality of learning becomes important (Johnson et al., 2008). Usman (2011) states that teachers are positions or professions that require specialized skills as teachers. One of them is the possibility that in an open discussion room with students where encouraged them to ask lots of questions, the teacher may not necessarily be able to answer a lot (Kador, Chatterjee, \& Hannan, 2017). The quality of learning is a determining factor in improving the quality of education (Irmayani \& et al., 2018). As a process where people learn (Cooper \& et al., 2020), The teacher has a professional responsibility to improve his abilities (Lauermann, 2014).

This research described, analyzed, and sought the meaning of the interrelationship between ICT education and training variables, professionalism, and the performance of elementary school teachers in the KKG group Telawang Banjarmasin City on the quality of learning. The purpose is (1) to describe about ICT education and training, professionalism, and performance of elementary school teachers in KKG Group Telawang, Banjarmasin on the quality of learning, (2) to determine the effect of ICT education and training on the performance of elementary school teachers in the KKG group Telawang, Banjarmasin, (3) to know the effect of professionalism on the performance of elementary school teachers in the KKG group Telawang, Banjarmasin, (4) to know the effect of education and ICT training of elementary school teachers on the quality of learning in the KKG group Telawang, Banjarmasin, (5) to determine the effect of professionalism of elementary school teachers on the quality of learning in the KKG group Telawang, Banjarmasin, (6) to know the influence of elementary school teacher performance on the quality of learning in the KKG group Telawang, Banjarmasin, and (7) to know the influence of ICT education and training, professionalism, and performance together to the quality of learning in the KKG group Telawang, Banjarmasin.

\section{Assumptions and hypotheses}

Based on the research scope assuming education and training are needed to improve teachers' ability, knowledge, and skills in carrying out tasks even with different levels of implementation and ability. Someone has a professional nature at work; the quality of his work will increase to achieve high performance 
(McLoughlin \& Lee, 2008). All of this ultimately impacts the quality of learning, which is the intensity of the synergistic and systemic relationship between teacher learning, behavior, and impact of student learning, material, media, and learning climate in producing optimal learning processes and outcomes. Based on these assumptions and through the study of literature sources, a research hypothesis can be formulated. The hypothesis is becoming the main component because this influences the direction of the study (Bernard, 2020). Thus, the study hypothesizes that there is a positive and significant influence in ICT education and training on the performance and professionalism of elementary school teachers in the KKG group Telawang Banjarmasin City which has an impact on the quality of learning in the KKG.

\section{Relevant research}

According to Dede Triani Wesman (2013), in his thesis entitled The Effect of Education and Training on Employee Performance in the Department of Industry and Trade Pekanbaru City, data analysis results using the Product
Moment formula value of 0.632 (high). It means that the relationship between education and training has a positive relationship with employee performance with a coefficient of determination of $39.9 \%$.

\section{Frame of through}

The illustration relationships of causality (causal relationships), namely the effect of ICT education and training, and professionalism on the quality of learning and its impact on teacher performance in the form of a chart, shown in Figure 1. As illustrated in Figure 1, the research framework shows several aspects of the relationship between ICT education and training, professionalism, the quality of learning, and teacher performance. ICT education and training are given to develop the capabilities needed (Erstad, 1997) to achieve goals/objectives. Teacher professionalism has a direct influence on the achievement of learning objectives (Hakim, 2015), where the excellent performance of a teacher can improve student learning outcomes (Kintu et al., 2017).

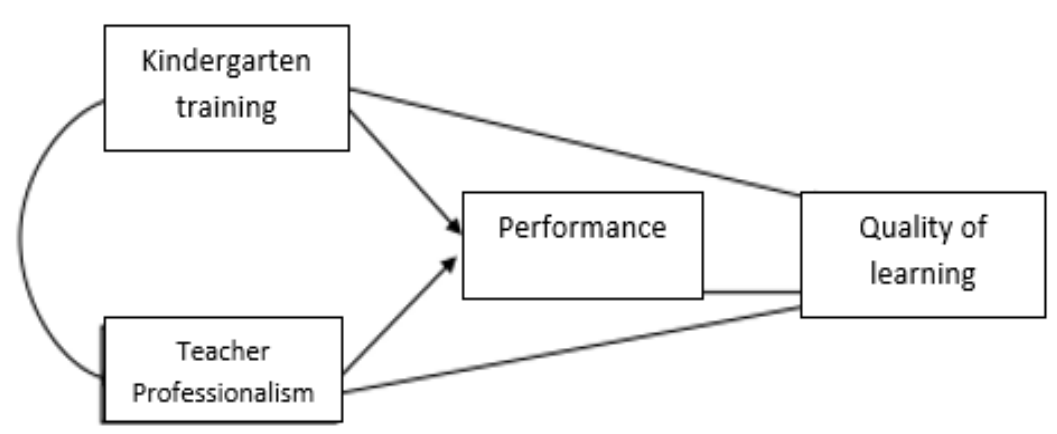

\section{Material and Methods \\ Research design}

This study uses a quantitative approach. Quantitative is not the same as qualitative based on literature sources (Johaneck, 2000). The quantitative approach means that all data or information extracted using a questionnaire is realized in the form of numbers and then analyzed with statistical techniques to determine the influence between variables. In conducting this research, the writer uses descriptive analysis research methods and verification methods. The descriptive analysis method is a method of research carried out to describe and explain the situation regarding the facts, the characteristics of the population based on the data that has been collected. Then arranged systematically and then analyzed to get conclusions to find out about the use of ICT education and training, teacher professionalism, teacher performance, and quality of learning. While the verification method determines the causality relationship (cause and effect relationship) between variables through hypothesis testing by statistical calculations, a verification approach determines the effect of ICT education and 
training, as well as professionalism on the quality of learning and its impact on the performance of elementary school teachers in the KKG Group in Telawang, Banjarmasin.

\section{Population and sample Population}

A population is an object or subject in an area that meets certain conditions related to the research problem. The population can be people, objects, plants, events, and symptoms with specific characteristics and are transparent (Wiyono, 2004). This study population is comprised of elementary school teachers who are members of the Teacher Working Group (KKG) Telawang Banjarmasin City, amounting to 98 people.

\section{Sample}

Samples will be taken from the population by using probability sampling. This sampling technique provides an equal opportunity for each member of the population to be elected as a sample member (Sugiyono, 2008). However, to facilitate the calculation, the number of respondents will be fulfilled to 79 respondents with a confidence level of $5 \%$.

\section{Research instrument}

This study uses a questionnaire. Based on nature and purpose, four types of instruments are used, namely: (1) Questionnaire to obtain data on ICT training, (2) Questionnaire to obtain data on teacher professionalism, (3) Questionnaire to obtain data on teacher performance, and (4) Questionnaire for obtaining data about the quality of learning. Based on this foundation, in this study, to reveal ICT training, professionalism, teacher performance, and learning quality of elementary school teachers who are members of the KKG Group Telawang Banjarmasin Banjarmasin, a Likert Scale model is used. The Likert Scale Model is most often used to measure respondents' attitudes, opinions, and perceptions of an object (Usman, 2011).

\section{Data collection}

As previously described, quantitative data are based on a specified scope with the number of populations sampled. The data referred to in this study are a series of figures that describe work motivation, organizational culture, and teacher performance. Data collection techniques that are considered appropriate for obtaining data use a Likert scale that provides alternative answers 1 to 5 for the data collection on ICT training, professionalism, teacher performance, and quality of learning. For this study, the questionnaires above were tested for both validity and reliability.

\section{Data analysis}

\section{Descriptive analysis}

Following this study's purpose, the research data collected were analyzed by describing the phenomena in a data tabulated in tabular form. In other words, the data are directly observed (Wehby, Symons, \& Shores, 1995). This technique is used to see each variable's tendency, namely by calculating the mean, average value, standard deviation, and variance.

\section{Verification analysis}

The verification analysis is "checking whether or not it is explained to test away with or without improvements that have been carried out elsewhere by overcoming problems similar to life." The rank in each research variable can be seen from the comparison between the actual and ideal scores.

\section{Results \\ Data description}

This research was conducted with the encouragement of permission letter from the Head of the Master of Education Management Program at Lambung Mangkurat University No.081/UN8.1.2.6.6 dated 23 April 2019 concerning Research/Observation Permit and Recommendation Letter (research permit) from the Head of the Banjarmasin City Education Office 070/389-Sekr / Dispendik / 2019 dated 24 April 2019 concerning permission to research the KKG Banjarmasin City. Based on the research permit, the researchers began to research by distributing 79 questionnaires to 79 elementary school teachers who 
are members of the KKG group in Telawang Banjarmasin City.

Distribution of ICT education and training variable scores

Data of teachers' answers to the variables of education and ICT training for elementary school teachers in the KKG Group in Telawang, Banjarmasin, are from the level of Always (SL), Frequently (SR), Sometimes (KK), Rarely (JR), and Never (TP) ). A small proportion of teachers always and sometimes implement ICT training outcomes in the amount of $29.75 \%$ and $26.52 \%$, some often carry out ICT training outcomes in the amount of $42.29 \%$. Simultaneously, a minimal number which rarely or never carries out ICT training results in their work is equal to $1.27 \%$ and $0.17 \%$. The distribution of scores from the variables and the ICT training of elementary school teachers from the Banjarmasin Telawang Cluster can be illustrated (Figure 2).

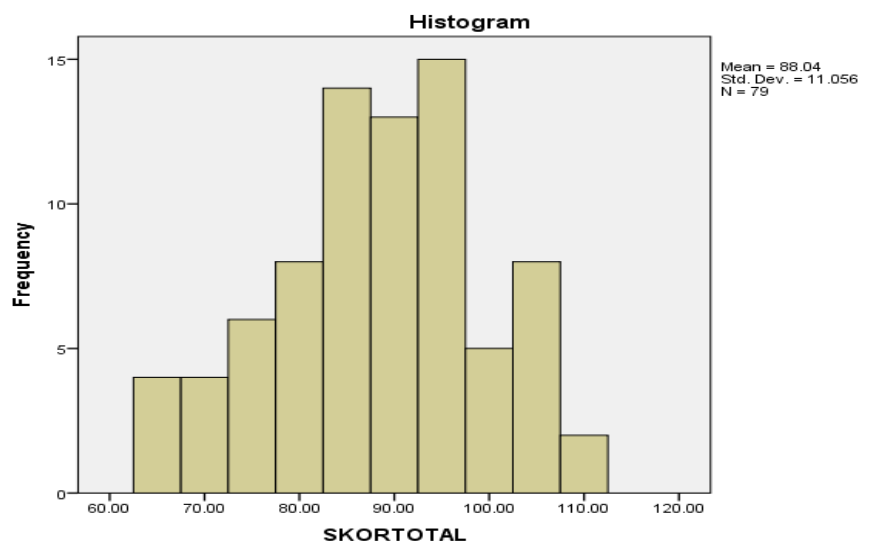

Figure 2. ICT education and training histogram

55.7\%. A small proportion often has

Figure 2. above shows the education and training scores normally distributed with 88.04 and a median of 88.00. The mean value appears smaller than the median. In other words, the distribution is negatively skewed, which means that teacher ICT education and training is high. Data processing results show that most of the ICT teacher education and training scores of 79 teachers, or $75 \%$ were in high teacher ICT education and training. The 20 teachers or $25 \%$ were in teacher ICT education and training, and there were no teachers or $0 \%$ are in the low teacher ICT education and training. Therefore, these data interpret that, in general, the teachers of the KKG Group in Telawang Banjarmasin have high teacher work discipline scores.

Variable score distribution of teacher professionalism

Based on the research data, some teachers always have professionalism, which is equal to professionalism, which is equal to $34.34 \%$. While a tiny portion sometimes, rarely or never has the professionalism in their work, it is equal to $8.73 \%, 0.47 \%$, and $0.79 \%$. The distribution of scores from the variables of elementary school teacher professionalism from the Banjarmasin Telawang Group can be illustrated in the Figure 3. From figure 3 above shows, teacher professionalism scores are generally distributed with a mean of 244.04 and a median of 249.00 . From the results of data processing, it was found that the majority of the teachers' professionalism scores of 76 teachers or $96 \%$ were at high teacher professionalism, three teachers, or $4 \%$ were at moderate teacher professionalism, and no teachers or $0 \%$ were at low teacher professionalism. Thus, these data interpret that, in general, the teachers of the KKG Group in Telawang Banjarmasin have high teacher professionalism scores. 


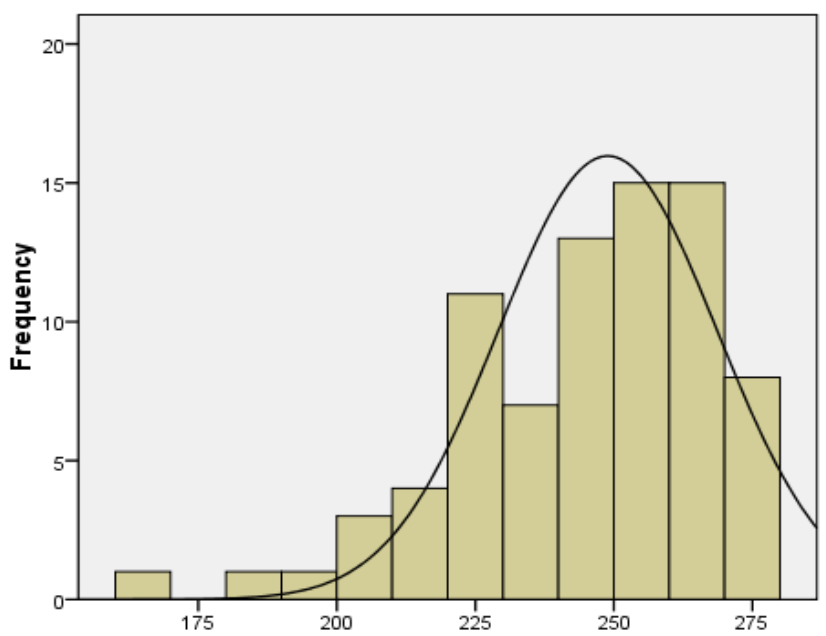

Figure 3. Teacher professionalism histogram

Distribution of teacher performance variable score

Based on research data, some teachers always have performance equal to $51.82 \%$ and $43.18 \%$. A tiny portion that sometimes rarely or never has a performance equal to $9.28 \%$, $0.46 \%$, and $1.26 \%$. The distribution of scores from the elementary school teacher performance variables from the Banjarmasin Telawang Cluster can be illustrated in the following Figure 4.

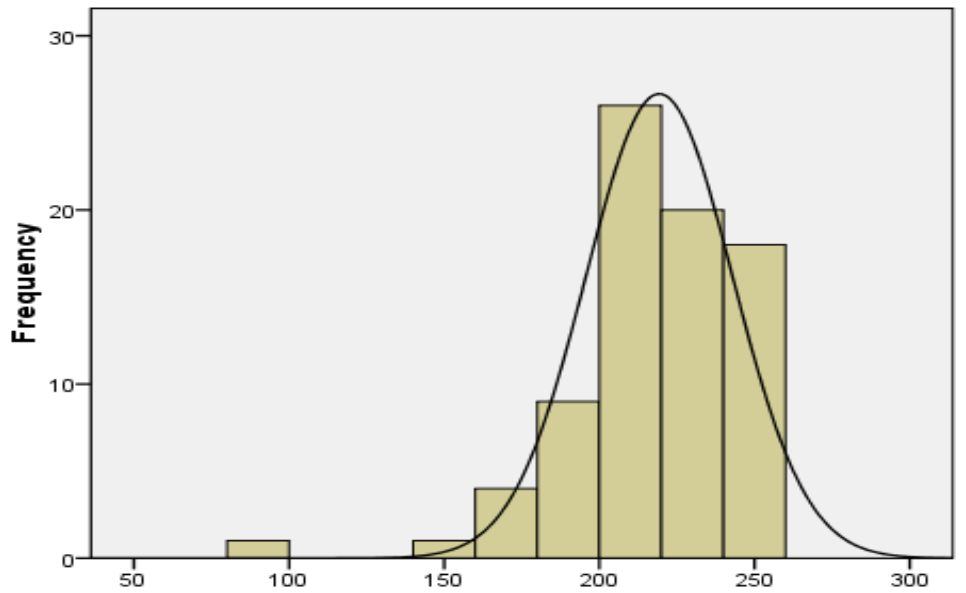

$\begin{aligned} \text { Mean } & =215.94 \\ \text { Std. Dev. } & =27.319 \\ N & =79\end{aligned}$

Figure 4. Performance teacher histogram

Figure 4 above shows the teacher performance scores generally distributed with a mean of 215.94 and a median of 219.00 . The mean value appears smaller than the median. In other words, the distribution is negatively skewed, which means that teacher performance is high. Based on the criteria for the position of each variable obtained through a comparison between the average position calculated with the ideal average and standard deviation, shows that most of the teacher performance scores of 72 teachers or $91 \%$ are at high teacher performance, six teachers or 8 $\%$ is in the performance of moderate teachers.
One teacher or $1 \%$ is in low teacher performance. Thus, these data interpreted that, in general, the teachers of the KKG Group in Telawang Banjarmasin have high teacher performance scores.

\section{Learning quality variable score distrivution}

Based on research data, a small portion of teachers always improves the quality of learning equal to $35.37 \%$, and some teachers often improve the quality of learning equal to $48.31 \%$. While a tiny portion that sometimes, rarely, or never improves the quality of learning that is by $14.34 \%, 1.07 \%$, and $0.92 \%$ 
(attachment 16). The distribution of scores from the variable quality of teacher learning incorporated in the Telawang Group
Banjarmasin City can be illustrated in the following Figure 5.

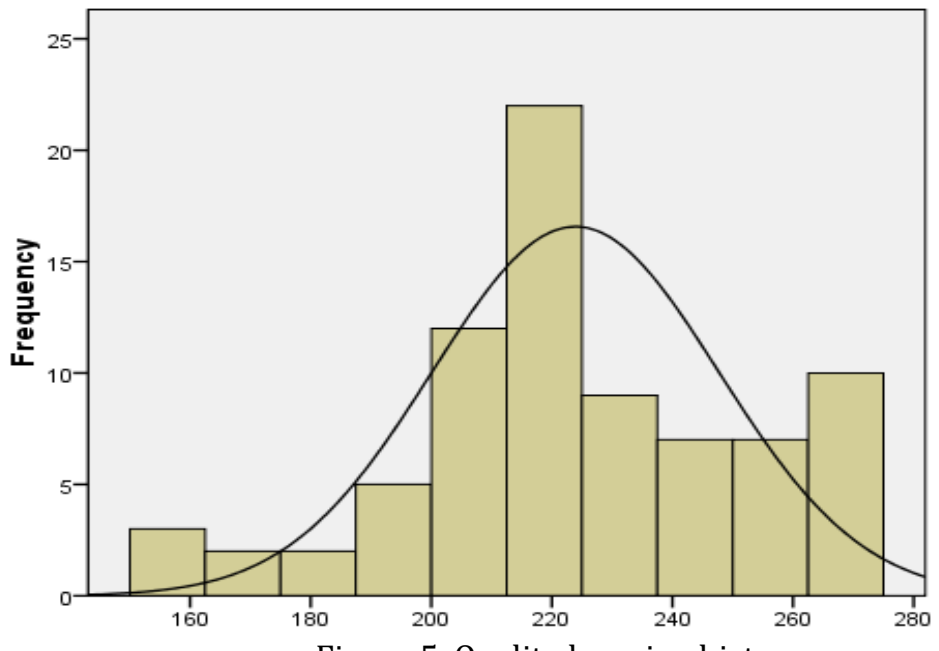

Mean $=224.37$
Std. Dev. $=27.833$
$N=79$

Figure 5. Quality learning histogram

Figure 5. shows the quality scores of learning distributed with a mean of 224.37 and a median of 219.00 . The mean value is higher than the median; in other words, the distribution is positively skewing, which means that the quality of learning carried out by the teacher is high. Most of the Learning Quality scores of 70 teachers or $89 \%$ are at high Learning Quality, nine teachers or $11 \%$ are at medium Learning Quality, and no teachers or $0 \%$ are at low Learning Quality. Thus, based on these data interpreted that in general, the teachers of the KKG Group in Telawang
Banjarmasin have a high Learning Quality score.

\section{Verification analysis}

To determine the ranking in each variable can be seen from the comparison between the actual and ideal scores. The following are respondents' responses to the variables of ICT education and training, professionalism, performance, and quality of learning.

Table 1. Respondents response to variables ICT education and training, professionalism, teacher performance, and learning quality

\begin{tabular}{lcccc}
\multicolumn{1}{c}{ Instrument } & $\begin{array}{c}\text { Number } \\
\text { of Items }\end{array}$ & $\begin{array}{l}\text { Actual } \\
\text { Score }\end{array}$ & \multicolumn{1}{c}{$\begin{array}{l}\text { Ideal } \\
\text { Score }\end{array}$} & \% of Actual Score \\
\hline ICT Education and Training & 22 & 6.955 & 8.690 & 80.03 \\
Professionalism & 55 & 19.279 & 21.725 & 88.74 \\
Teacher Performance & 50 & 17.059 & 19.750 & 86.37 \\
Learning Quality & 54 & 17.725 & 21.330 & 83.10 \\
\hline
\end{tabular}

Source: Processed primary data, 2020

The above calculation concludes that respondents' responses to ICT education and training variables are $80.03 \%$, and the quality of learning is $83.10 \%$. It means that responses, according to respondents, are excellent. As for the professionalism variable of $88.74 \%$ and the performance of $86.37 \%$,

\section{Data analysis}

\section{Normality test}

The normality test determines whether the collected data has a normal distribution or not. If the test is reasonable, the results of statistical calculations can be generalized to the population.The normality test is done both 
manually and using the SPSS computer program. In this study, the normality test uses the Kolmogorov-Smirnov test.

Table 2. Result of Normality Test

One-Sample Kolmogorov-Smirnov Test

\begin{tabular}{|c|c|c|c|c|c|}
\hline & & Training & Professionalism & Performance & Quality \\
\hline $\mathrm{N}$ & & 79 & 79 & 79 & 79 \\
\hline \multirow{2}{*}{ Normal Parameters, ${ }^{b}$} & Mean & 88.0380 & 244.0380 & 215.9367 & 224.3671 \\
\hline & Std. Deviation & 11.05632 & 22.81556 & 27.31879 & 27.83292 \\
\hline \multirow{3}{*}{$\begin{array}{l}\text { Most Extreme Differ- } \\
\text { ences }\end{array}$} & Absolute & .053 & .129 & .114 & .090 \\
\hline & Positive & .051 & .087 & .106 & .088 \\
\hline & Negative & -.053 & -.129 & -.114 & -.090 \\
\hline \multicolumn{2}{|c|}{ Kolmogorov-Smirnov Z } & .471 & 1.148 & 1.017 & .797 \\
\hline \multicolumn{2}{|c|}{ Asymp. Sig. (2-tailed) } & .980 & .143 & .253 & .549 \\
\hline
\end{tabular}

a. Test distribution is Normal; b. Calculated from data

Source: Processed primary data, 2020.

Based on the SPSS output table, it is known that the Asymp significance value. Sig. (2tailed) training is 0.980 , the professionalism of teachers is 0.143 , the value of teacher performance is 0.253 , and the quality of learning is 0.549 , so it can be concluded that the variable data of training, professional teachers, teacher performance, and quality of learning are customarily distributed because the value exceeds from 0.05 (5\%). So, according to the decision making in the Kolmogorov-Smirnov normality test above, it can be concluded that the assumptions or normality test requirements in the regression model have been fulfilled.

\section{Linearity test}

Linearity test is used to confirm whether the linear nature between the three independent variables and one dependent variable identified in theory is following or not with the results of existing observations.

Table 3. Result of linearity test (training on learning quality)

ANOVA Table

\begin{tabular}{|c|c|c|c|c|c|c|c|}
\hline & & & Sum of Squares & Df & Mean Square & $\mathrm{F}$ & Sig. \\
\hline \multirow{5}{*}{$\begin{array}{l}\text { Training } \\
\text { Quality }\end{array}$} & \multirow{3}{*}{$\begin{aligned} & \text { Between } \\
& * \text { Groups }\end{aligned}$} & Combined) & 43188.004 & 35 & 1233.943 & 3.078 & .000 \\
\hline & & Linearity & 19164.737 & 1 & 19164.737 & 47.811 & .000 \\
\hline & & $\begin{array}{l}\text { Deviation } \\
\text { from Linearity }\end{array}$ & 24023.267 & 34 & 706.567 & 1.763 & .054 \\
\hline & \multicolumn{2}{|c|}{ Within Groups } & 17236.350 & 43 & 400.845 & & \\
\hline & \multicolumn{2}{|c|}{ Total } & 60424.354 & 78 & & & \\
\hline
\end{tabular}

Source: Processed primary data, 2020.

The above table concluded that: 1) ANOVA table obtained the value of Linearity sig 0.054 is greater than 0.05. A significant linear relationship exists between ICT Training (X1) variables and the quality of learning $(\mathrm{Y}) ; 2$ ) Based on the F value: from the Anova table, the calculated $\mathrm{F}$ value is $1.763<\mathrm{F}$ Table 1.78 . Because the calculated $F$ value is smaller than the $F$ value of the table, thus, there is a significant linear relationship between the tables between ICT Education and Training (X1) variables, to the quality of learning (Y). 
Table 4. Result of linearity test (teacher professionalism in learning quality)

ANOVA Table

\begin{tabular}{|c|c|c|c|c|c|c|c|}
\hline & & & Sum of Squares & Df & Mean Square & $\mathrm{F}$ & Sig. \\
\hline \multirow{5}{*}{$\begin{array}{l}\text { PROFES- } \\
\text { SIONAL } \\
\text { QUALITY }\end{array}$} & \multirow{3}{*}{$\begin{array}{l}\text { Between } \\
\text { * Groups }\end{array}$} & (Combined) & 43026.771 & 47 & 915.463 & 1.631 & .076 \\
\hline & & Linearity & 26201.637 & 1 & 26201.637 & 46.688 & .000 \\
\hline & & $\begin{array}{l}\text { Deviation } \\
\text { from Linear- } \\
\text { ity }\end{array}$ & 16825.134 & 46 & 365.764 & .652 & 908 \\
\hline & \multicolumn{2}{|c|}{ Within Groups } & 17397.583 & 31 & 561.212 & & \\
\hline & \multicolumn{2}{|c|}{ Total } & 60424.354 & 78 & & & \\
\hline
\end{tabular}

Source: Processed primary data, 2020.

The table above concluded that: 1) ANOVA table, the obtained value of Linearity sig 0.908 is higher than 0.05 . There is a significant linear relationship between variables of Teacher Professionalism (X2) on the quality of learning (Y); 2) Based on the $F$ value: from the Anova table, the calculated $\mathrm{F}$ value is $0.652<\mathrm{F}$ Table 1.78. Because the calculated $F$ value is smaller than the $F$ value of the table, there is a significant linear relationship between Teacher Professionalism (X2) and the Quality of Learning (Y).

Table 5. Result of linearity test (performance on the learning quality)

ANOVA Table

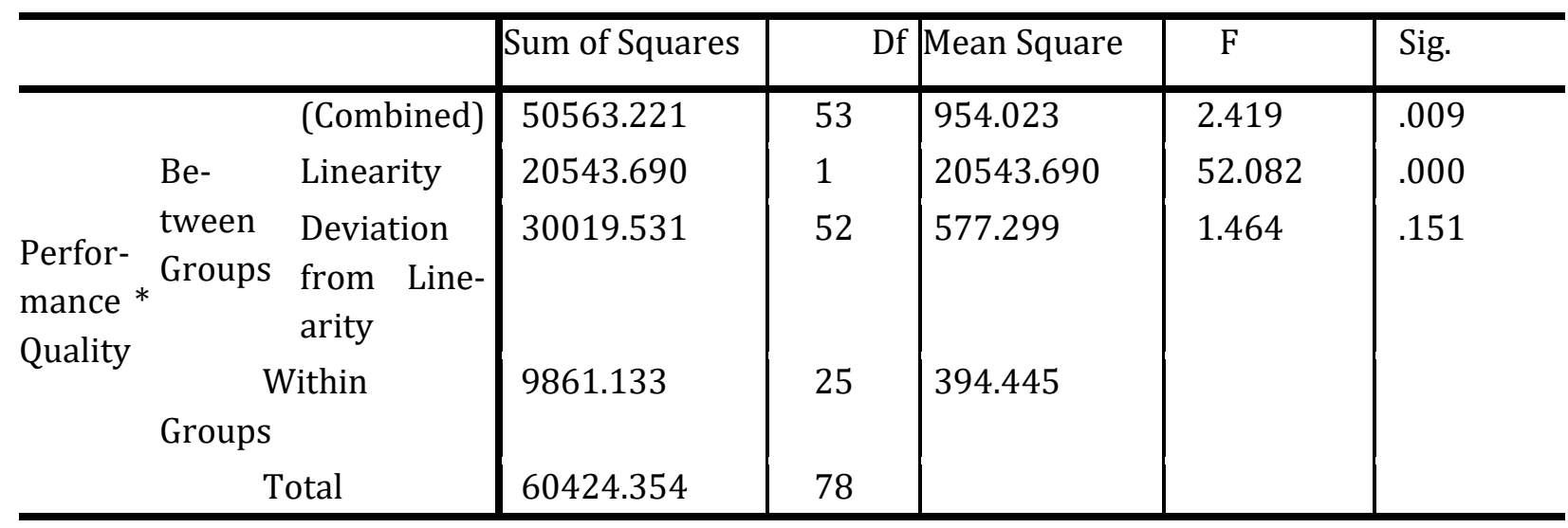

Source: Processed primary data, 2020

From the above table shows that: 1) From the ANOVA table, the Deviation from Linearity sig value of 0.151 is higher than 0.05 . A significant linear relationship occurs between the variable Teacher Performance (Z) to the quality of learning $(\mathrm{Y}) ; 2$ ) Based on the $\mathrm{F}$ value: from the Anova table, the calculated $\mathrm{F}$ value is $1.464<\mathrm{F}$ Table 1.78. Because the calculated $F$ value is smaller than the $F$ value of the table, there is a significant linear relationship between the tables between Teacher Performance (Z) and Learning Quality (Y).

\section{Multi-collinearity test}

The Multi-collinearity test analyzes whether the regression model found a correlation between independent variables. If there is a correlation, then there is a problem called multi-collinearity (multi co). A good regression model should not occur the correlation between independent variables. If a high correlation between the independent variables happens, then the relationship between independent variables and the dependent variable is disturbed. Decision guidance based on tolerance values between Teacher Performance $(Z)$ and Learning Quality (Y): 1) If the tolerance value is 
higher than 0.10 , there is no multi-collinearity in the regression model; 2) When the tolerance value is smaller than 0.10 , there is no multicollinearity in the regression model.

Decision guidelines based on VIF values (Variance Inflation Factor): 1) If the VIF value
$<10.00$, then there is no multi-collinearity in the regression model; 2) If the VIF value $>10.00$ means multi-collinearity occurs in the regression model.

Table 6. Result of multicollinearity test

\section{Coefficients}

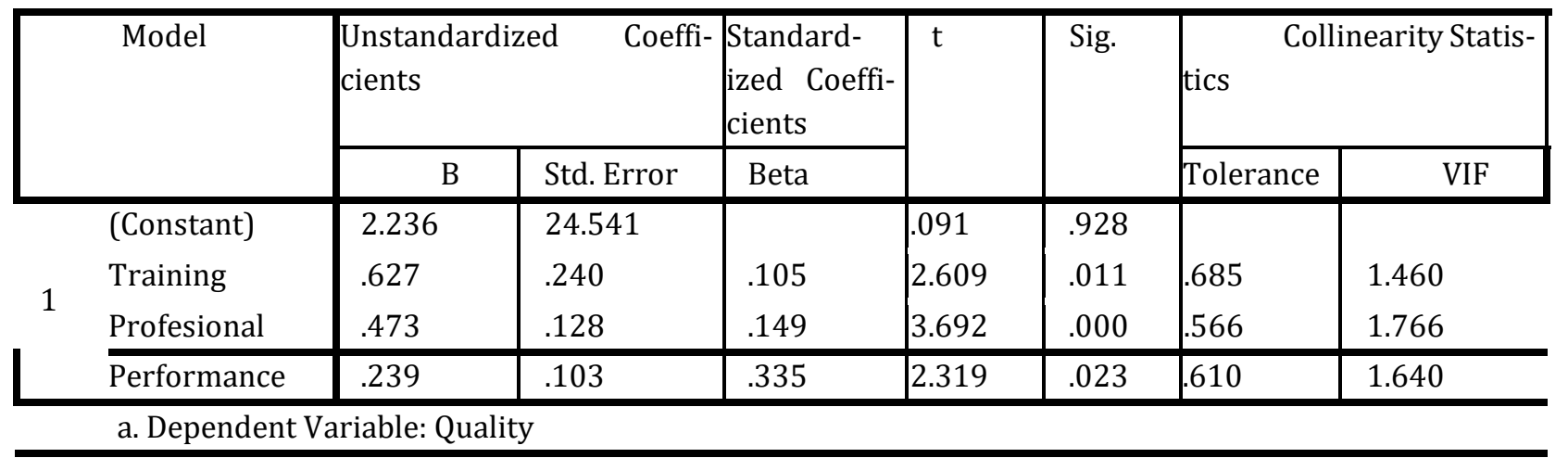

Source: Processed primary data, 2020.

Based on the output table "Coefficients" in the "Collinearity Statistics" section known Tolerance values for the variable ICT Training (X1) with a value of 0.685 , Teacher Professionalism (X2) with a value of 0.566 , Teacher performance $(\mathrm{Z})$ with a value of 0.610 greater 0.10 . Meanwhile, the VIF value for the ICT Training (X1) variable is 1.460 Teacher Professionalism (X2) is 1.766 Teacher performance (Z) is 1.640 less than 10.00. Refers to the basis of decisionmaking in the multi-collinearity test, it was concluded that there were no multi-collinearity symptoms in the regression model.

\section{Path analysis}

The path analysis is used if, in theory, we are confident in dealing with problems related to cause and effect. The goal is to explain the direct and indirect effects of a set of variables, as causal variables, on other variables, which are effect variables.

\section{Simple regression analysis}

Regression analysis is to determine the effect of one or more independent variables on the dependent variable. In this study revealed the influence between ICT education and training on teacher performance, teacher professionalism on teacher performance, ICT education and training on learning quality, teacher professionalism on learning quality, and teacher performance on learning quality analyzed by simple regression. The following regression coefficients are illustrated through the table:

- The influence between ICT education and training performance

Table 7. Regression coefficients of ICT education and training on teacher performance Coefficients

\begin{tabular}{|c|c|c|c|c|c|c|}
\hline & \multirow[t]{2}{*}{ Model } & \multicolumn{2}{|c|}{ Unstandardized Coefficients } & \multirow{2}{*}{\begin{tabular}{|c|}
$\begin{array}{l}\text { Standardized } \\
\text { Coefficients }\end{array}$ \\
Beta
\end{tabular}} & \multirow[t]{2}{*}{$\mathrm{t}$} & \multirow[t]{2}{*}{ Sig. } \\
\hline & & B & Std. Error & & & \\
\hline \multirow{2}{*}{1} & (Constant) & 113.547 & 22.042 & & 5.151 & .000 \\
\hline & Training & 1.163 & .248 & .471 & 4.681 & .000 \\
\hline
\end{tabular}

A. Dependent Variable: Performance

Source: Processed primary data, 2020. 
- The influence of teacher professionalism on teacher performance

Table 8. The regression coefficient of teacher professionalism against teacher performance

\begin{tabular}{|c|c|c|c|c|c|}
\hline \multirow[t]{2}{*}{ Model } & \multicolumn{2}{|c|}{ Unstandardized Coefficients } & \multirow{2}{*}{\begin{tabular}{|c} 
Standardized \\
Coefficients
\end{tabular}} & \multirow[t]{2}{*}{$\mathrm{t}$} & \multirow[t]{2}{*}{ Sig. } \\
\hline & B & Std. Error & & & \\
\hline (Constant) & 41.467 & 26.828 & & 1.546 & .126 \\
\hline Professional & .715 & .109 & .597 & 6.531 & .000 \\
\hline
\end{tabular}

a. Dependent Variable: performance

Source: Processed primary data, 2020

- The Effect of ICT Education and Training on Learning Quality

Table 9. Regression coefficients of ICT education and training on learning quality

\section{Coefficients}

\begin{tabular}{|c|c|c|c|c|c|c|}
\hline \multirow{2}{*}{\multicolumn{2}{|c|}{ Model }} & \multicolumn{2}{|c|}{ Unstandardized Coeffi- } & \multirow{2}{*}{\begin{aligned} \multicolumn{2}{|l}{$\begin{array}{l}\text { tandard- } \\
\text { ized Coeffi- } \\
\text { cients }\end{array}$} \\
Beta \end{aligned}} & \multirow[t]{2}{*}{$\mathrm{t}$} & \multirow[t]{2}{*}{ Sig } \\
\hline & & B & ror $\quad$ Std. Er- & & & \\
\hline \multirow{2}{*}{1} & (Constant) & 99.553 & 21.032 & & 4.733 & .000 \\
\hline & Training & 1.418 & .237 & .563 & 5.980 & .000 \\
\hline
\end{tabular}

a. Dependent Variable: QUALITY

Source: Processed primary data, 2020

- The Effect of Teacher Professionalism on Learning Quality

Table 10. Regression coefficient of teacher professionalism on learning quality

Coefficients

\begin{tabular}{|c|c|c|c|c|c|}
\hline \multirow[b]{2}{*}{ Model } & \multicolumn{2}{|c|}{$\begin{array}{l}\text { Unstandardized } \\
\text { Coefficients }\end{array}$} & \multirow{2}{*}{\begin{tabular}{|c|}
$\begin{array}{c}\text { Standardized } \\
\text { Coefficients }\end{array}$ \\
Beta \\
\end{tabular}} & \multirow[b]{2}{*}{$\mathrm{t}$} & \multirow[b]{2}{*}{ Sig } \\
\hline & B & Std. Error & & & \\
\hline (Constant) & 28.328 & 25.642 & & 1.105 & .273 \\
\hline $\begin{array}{l}\text { Profesionalisme } \\
\text { Guru (X2) }\end{array}$ & .803 & .105 & .659 & 7.678 & .000 \\
\hline
\end{tabular}

a. Dependent Variable: Learning Quality (Z)

Source: Processed primary data, 2020. 
- The Effect of Teacher Performance on Learning Quality

Table 11. Regression coefficient teacher performance on learning quality Coefficients

\begin{tabular}{|c|c|c|c|c|c|c|}
\hline & \multirow[b]{2}{*}{ Model } & \multicolumn{2}{|c|}{$\begin{array}{l}\text { Unstandardized } \\
\text { Coefficients }\end{array}$} & \multirow{2}{*}{\begin{tabular}{|c}
$\begin{array}{l}\text { Standardized } \\
\text { Coefficients }\end{array}$ \\
Beta
\end{tabular}} & \multirow[t]{2}{*}{$\mathrm{t}$} & \multirow[t]{2}{*}{ Sig } \\
\hline & & B & Std. Error & & & \\
\hline \multirow[t]{2}{*}{1} & (Constant) & 96.088 & 20.529 & & 4.681 & .000 \\
\hline & Teacher Performance (Y) & .594 & .094 & .583 & 6.298 & .000 \\
\hline
\end{tabular}

a. Dependent Variable: Learning Quality (Z)

Source: Processed primary data, 2020.

\section{Multiple regression path analysis}

To determine the effect of ICT education and training variables through teacher performance on learning quality and teacher professionalism through teacher performance on learning quality-analyzed simultaneously by multiple linear regression. Interpretation of path analysis results with a summary of results in the following table.

Table 12. Model 1 training, teacher professionalism on teacher performance

\begin{tabular}{|l|c|l|l|l|}
\hline Variable & Path Coefficient & $\mathbf{T}$ & $\mathbf{P}$ & \multirow{2}{*}{$\mathbf{R}^{\mathbf{2}}$} \\
\hline Training & 0.356 & 2.056 & 0.043 & \multirow{2}{*}{0.390} \\
\hline Teacher Professionalism & 0.483 & 4.588 & 0.000 & \\
\hline
\end{tabular}

Source: Processed primary data, 2020.

Table 13. Professionalism and performance of work teachers towards learning quality

\begin{tabular}{|l|c|l|l|l|}
\hline Variable & Path Coefficient & $\mathbf{T}$ & $\mathbf{P}$ & \multirow{2}{*}{$\mathbf{R}^{\mathbf{2}}$} \\
\hline Training & 0.105 & 2.609 & 0.11 & \\
\hline Teacher Professionalism & 0.149 & 3.629 & 0.000 & \multirow{2}{*}{0.523} \\
\hline Teacher Performance & 0.335 & 2.319 & 0.023 & \\
\hline
\end{tabular}

Source: Processed primary data, 2020.

\section{Hypothesis testing}

Table 14. Summary of hypothesis testing decisions $\mathrm{H}_{1}, \mathrm{H}_{2}, \mathrm{H}_{3}, \mathrm{H}_{4}$ dan $\mathrm{H}_{5}$

\begin{tabular}{|l|l|l|}
\hline Hypothesis & P & Decision \\
\hline $\begin{array}{l}\mathrm{H}_{1}: \text { There is an influence between education and training on the } \\
\text { quality of learning in the KKG Group Tela-wang Banjarmasin City. }\end{array}$ & 0.011 & Accept \\
\hline $\begin{array}{l}\mathrm{H}_{2}: \text { There is an influence between teachers' professionalism on the } \\
\text { quality of learning in the KKG Group in Telawang, Banjarmasin. }\end{array}$ & 0.000 & Accept \\
\hline $\begin{array}{l}\mathrm{H}_{3}: \text { There is an influence between teachers' performance on the } \\
\text { quality of learning in the KKG Group Telawang Banjarmasin City. }\end{array}$ & 0.023 & Accept \\
\hline $\begin{array}{l}\mathrm{H}_{4}: \text { There is an influence between education and training on teach- } \\
\text { ers' performance in the KKG group Telawang Banjarmasin. }\end{array}$ & 0.043 & Accept \\
\hline $\begin{array}{l}\text { H5: There is an influence between professionalism on the perfor- } \\
\text { mance of teachers in KKG Group Telawang Banjarmasin. }\end{array}$ & 0.000 & Accept \\
\hline
\end{tabular}

Source: Processed primary data, 2020. 
Table 15. Summary of hypothesis testing decision H6 and H7

\begin{tabular}{|c|c|c|c|}
\hline \multirow{2}{*}{ Hypothesis } & \multicolumn{2}{c|}{ Relationship Coefficient } & \multirow{2}{*}{ Decision } \\
\cline { 2 - 4 } & Direct & 0.119 & Accept \\
\hline $\begin{array}{l}\mathrm{H}_{6} \text { : Performance is an intermediary between } \\
\text { the influence of education and training quality } \\
\text { in KKG Group Telawang Banjarmasin. }\end{array}$ & 0.105 & 0.161 & Accept \\
\hline $\begin{array}{c}\text { H7: Performance is an intermediary between } \\
\text { the influence of teachers' professionalism and } \\
\text { the quality of learning in the KKG Group Tela- } \\
\text { wang Banjarmasin City. }\end{array}$ & & 0.149 & \\
\hline
\end{tabular}

Source: Processed primary data, 2020.

\section{Multiple regression path analysis}

Furthermore, to measure the real level of influence of ICT education and training variables, teacher professionalism, and teacher performance with the quality of learning, an $\mathrm{F}$ test.

Table 16. Result of F test variable of ICT education and training, teacher professionalism, and teacher Performance together

\begin{tabular}{|c|c|c|c|c|c|c|}
\hline \multicolumn{7}{|c|}{ ANOVA } \\
\hline \multicolumn{2}{|c|}{ Model } & Sum of Squares & Df & Mean Square & $\mathrm{F}$ & Sig. \\
\hline \multirow{3}{*}{1} & Regression & 32153.364 & 3 & \multirow{3}{*}{$\begin{array}{l}10717.788 \\
376.947\end{array}$} & \multirow[t]{3}{*}{28.433} & \multirow[t]{3}{*}{$.000^{\mathrm{b}}$} \\
\hline & Residual & 28270.990 & 75 & & & \\
\hline & Total & 60424.354 & 78 & & & \\
\hline
\end{tabular}

a. Dependent Variable: KUALITAS

b. Predictors: (Constant), Professional, Training, Performance

Source: Processed primary data, 2020.

\section{Coefficient of determination}

Table 17. Result of determination coefficient test model I

\section{Model Summary}

\begin{tabular}{|c|r|r|r|r|}
\hline Model & $\mathrm{R}$ & $\mathrm{R}$ Square & Adjusted R Square & Std. An error of the Estimate \\
\hline 1 & $.625^{\mathrm{a}}$ & .390 & .374 & 21.60840 \\
\hline
\end{tabular}

a. Predictors: (Constant), Training, Professional

Source: Processed primary data, 2020.

Table 18. Result of determination coefficient Test Model II

Model Summary

\begin{tabular}{|c|c|c|c|c|}
\hline Model & $\mathrm{R}$ & $\mathrm{R}$ Square & Adjusted R Square & Std. An error of the Estimate \\
\hline 1 & $.729^{\mathrm{a}}$ & .532 & .513 & 19.41511 \\
\hline
\end{tabular}

a. Predictors: (Constant), Performance, Training, Professional

b. Dependent Variable: Quality

Source: Processed primary data, 2020.

Summary of pathways 
Based on path analysis with models 1 and 2, it can be concluded that: (a) The Influence of ICT Education and Training on Teacher Performance from the results of a simple regression analysis implies that ICT education and training have a significant effect on the performance of elementary school teachers in KKG Group Telawang Banjarmasin City; (b) The Effect of Teacher Professionalism on Teacher Performance from the results of a simple regression analysis implies that teacher professionalism has a significant effect on the performance of elementary school teachers in the KKG Group Telawang Banjarmasin; (c) The Influence between ICT Education and Training on Learning Quality from the results of a simple regression analysis implies that ICT education and training have a significant effect on the quality of learning of elementary school teachers in the KKG Cluster Telawang, Banjarmasin; (d) The Effect of Teacher Professionalism on Learning Quality from the results of a simple regression analysis implies that teacher professionalism significantly affects the quality of primary school teacher learning in the KKG Group in Telawang, Banjarmasin; (e)The Influence Between Teacher Performance on Learning Quality from the results of a simple regression analysis implies that teacher performance significantly affects the quality of learning of elementary school teachers in the KKG Group in Telawang, Banjarmasin; (f) Analysis of the influence of ICT education and training through teacher performance on the quality of learning can be concluded that directly ICT education and training through teacher performance has a significant influence on the quality of learning.

\section{Discussion \\ ICT education and training, teacher profes- sionalism, and teacher performance}

Changes in science, information, and communication technology resulted in a comprehensive competition, especially in education. To be able to compete, the teacher, as an educator, must be able to prepare themselves to develop and improve their ability in the field of information and communication technology.
Therefore, teachers are always required to improve their performance to realize a good and quality learning process. Many ways can be done to become a competent teacher, by hone self-study, doing research, group discussions, and following training. These efforts are, of course, to improve competence, improve professionalism, improve performance, and ultimately estuary is improving the quality of learning.

\section{The influence ICT education and training, on teacher performance}

The study results stated that there was a positive and significant influence between the variables of ICT education and training on the performance of elementary school teachers who are members of the KKG Group Telawang Banjarmasin. The path analysis results show that ICT education and training (X1) significantly influence teachers' workability (Y).

\section{The influence of teacher professionalism on teacher performance}

Through this study, there was a positive and significant effect between the variables of teacher professionalism on the performance of elementary school teachers who were members of the Banjarmasin Telawang Cluster. The path analysis shows that teacher professionalism (X2) has a significant effect on the workability of teachers (Y). Professional teachers are well-educated and well-trained people with rich experience in their fields. Teachers who are required to work professionally master the field of work, creative, innovative, to produce high performance.

\section{The influence of ICT education and training on learning quality}

The path analysis results show that ICT education and training (X1) significantly influence learning quality ( $\mathrm{Z}$ ). Teachers who get education and training are at least able to demonstrate teacher learning behavior that can be seen from their performance such as (1) building positive attitudes of students towards learning and the profession, (2) mastering the scientific discipline, (3) understanding 
students' uniqueness, (4) mastering the management of learning that educates, and (5) develops personality and professionalism.

\section{The effect between teacher professionalism on learning quality}

The path analysis shows that teacher professionalism (X2) has a significant effect on the quality of learning (Z). Professional teachers will undoubtedly give all their abilities in the interest of advancing the quality of education. The more professional the teacher, the more it can improve the learning process, and the more the quality of achievement of learning objectives is improved.

\section{The effect of teacher performance on learn- ing quality}

It was shown through this research that there was a positive and significant effect between the teacher performance variables on the quality of learning of elementary school teachers who were members of the Banjarmasin Telawang Cluster. Adequate learning conditions can be achieved if the teacher can manage learners and learning tools, establish interpersonal relationships with students, and control them in a pleasant atmosphere to achieve learning goals.

The influence of ICT education and training, teacher professionalism, and teacher performance together on learning quality

A positive and significant effect between ICT education and training, teacher professionalism, and teacher performance on the quality of learning was found. The quality of learning depends on teachers' professional abilities, especially in providing ease of learning to students effectively and efficiently and through active, creative, and fun learning. Therefore, a teacher's role in building learning equality through the dimension of professionalism is needed to improve professionalism so that the quality of our education continues to improve. Thus, we are not further behind compared to neighboring countries and other nations that are more advanced. Teacher placement, under their expertise, absolutely must be done. If the teacher is given a task that is not per his expertise will result in decreased work methods, and the results of their work will also cause dissatisfaction with themselves.

\section{Conclusion}

The study results concluded that (1) the purpose of improving teacher performance is to realize a good and quality learning process that requires education and training to improve professionalism competency, performance, and quality of learning, (2) there is an influence between ICT education and training on the performance of elementary school teachers in the KKG Group Telawang Banjarmasin with ICT education and training, (3) The teacher professionalism has influence on the performance of elementary school teachers in the KKG Group Telawang Banjarmasin with teacher professionalism, (4) There is an influence between ICT education and training on quality elementary school teacher learning in KKG Group Telawang Banjarmasin with ICT education and training, (5) the teacher professionalism has influence on the quality of elementary school teacher learning in KKG Group Telawang Banjarmasin with teacher professionalism, (6) There is an influence between ICT education and training on quality the learning outcomes of elementary school teachers in the KKG Group Telawan Banjarmasin with ICT education and training, (7) There is an influence of ICT education and training, teacher professionalism, and teacher performance on the quality of learning carried out by elementary school teachers who are part of the KKG Group Telawang Banjarmasin.

\section{Acknowledgment}

The author say thanks to BTIKP of Kalimantan Selatan Province, Universitas Lambung Mangkurat, Banjarmasin.

\section{References}

Afshari, M., \& et al. (2009). Factors affecting teachers' use of information and communication technology. International Journal of Instruction, 2(1), 77-104.

Andoh, C. (2012). Factors influencing teachers' adoption and integration of information and communication technology into teaching: A review of the literature. International Journal of Education and Development using Information and Communication Technology (IJEDICT), 8(1), 136-155. 
Bernard, O. (2020). Refutation in Research: How to Improve Publication Quality. Annals of Economics and Statistics, (138), 2148.

Cassidy, M. (1921). What Is a Teacher? The Journal of Education, 93(16 (2326)), 439-439.

De Witte, K., Titl, V., Holz, O., \& Smet, M. (2019). Overview of education systems. In financing quality education for all: the funding methods of compulsory and special needs education (pp. 25-40). Leuven (Belgium0: Leuven University Press.

Erstad, M. (1997). Empowerment and organizational change. International Journal of Contemporary Hospitality Management, 9(7), 325-333.

Ghavifekr, S., \& Rosdy, W. (2015). Teaching and learning with technology: Effectiveness of ICT integration in schools. International Journal of Research in Education and Science (IJRES), 1(2), 175-191.

Hakim, A. (2015). Contribution of competence teacher (pedagogical, personality, professional competence and social) on the performance of learning. The International Journal of Engineering and Science (IJES), 4(5), 01-12.

Jiang, K., Lepak, D., Hu, J., \& Baer, J. (2012). How does human resource management influence organizational outcomes? a meta-analytic investigation of mediating mechanisms. The Academy of Management Journal, 55 (6), 1264-1294.

Johaneck, C. (2000). Composition research: Issues in Context. In composing research: a contextualist paradigm for rhetoric and composition (pp. 8-27). University Press of Colorado.

Johnson, R. D., et al. (2008). An empirical examination of factors contributing to the creation of successful e-learning environments. International Journal of Human-Computer Studies, 66, 356-369.

Kador, T., Chatterjee, H., \& Hannan, L. (2017). The materials of life: Making meaning through object-based learning in twenty-first century higher education. In Carnell B. \& Fung D. (Eds.), Developing the Higher Education Curriculum: Research-Based Education in Practice (pp. 60-74). London: UCL Press.

Kintu, MJ et al. (2017). Blended learning effectiveness: the relationship between student characteristics, design features and outcomes. International Journal of Educational technology in Higher Education, 14(7), 1-20.
McLoughlin, C., \& Lee, M. J. (2008). The tgree P's of pedagogy for the networked society: personalization, participation, and productivity. International Journal of Teaching and Learning in Higher Education, 20(1), 10-27.

Nixon, P., \& et al. (2012). Leadership performance is significant to project success or failure: a critical analysis. International Journal of Productivity and Performance Management, 61(2), 204-216.

Santoro, D. (2011). Good teaching in difficult times: demoralization in the pursuit of good work. American Journal of Education, 118(1), 1-23.

Sugiyono (2018). Quantitative research methods. Bandung: CV Alfabeta.

Taunay, E. (2015). Pengembangan SDM berbasis kompetensi antara pengaruh budaya organisasi terhadap kinerja di lingkungan pendidikan. Jurnal Universitas Pandanaran, 1(2), 1-10.

Trianto. (2010). Mendesain model pembelajaran inovatif-progresif: konsep, landasan, dan implementasinya pada Kurikulum Tingkat Satuan Pendidikan (KTSP). Jakarta: Kencana.

Tóth-Pjeczka, K., Rapos, N., \& Szivák, J. (2019). Components, models and operational mechanisms of teacher collaboration. In Kowalczuk-Walêdziak M., Korzeniecka-Bondar A., Danilewicz W., \& Lauwers G. (Eds.), Rethinking Teacher Education for the 21st Century: Trends, Challenges and New Directions (pp. 283-299). Opladen; Berlin; Toronto: Verlag Barbara Budrich.

Usman, M. (2011). Menjadi guru profesional. Bandung: PT. Remaja Rosdakarya.

Wehby, J., Symons, F., \& Shores, R. (1995). A Descriptive analysis of aggressive behavior in classrooms for children with emotional and behavioral disorders. Behavioral Disorders, 20(2), 87-105.

Wiyono, B. B. (2018). The effect of self-evaluation on the principals' transformational leadership, teachers' work motivation, teamwork effectiveness, and school improvement. International Journal of Leadership in Education, 21(6), 705-725. DOI:10.1080/13603124.2017.1318960 
